\title{
A New Virus Isolated from Salmonid Fish
}

\author{
Myung-Joo Oh, Mamoru Yoshimizu, Takahisa Kimura \\ and Yoshio Ezura \\ Laboratory of Microbiology, Faculty of Fisheries, Hokkaido University, \\ Minato, Hakodate, Hokkaido 041, Japan
}

(Received July 18, 1994)

\begin{abstract}
An undescribed virus was isolated from the brain of coho salmon (Oncorhynchus kisutch), iwana (Salvelinus pluvius), rainbow trout $(O$. mykiss) and ayu (Plecoglossus altivelis), and ovarian fluid of masu salmon (O. masou) cultured in the northern part of Japan. The virus was isolated from both juveniles and adult fishes. Diseased fish showed abnormal swimming movement and were lethargic. The virus replicated, inducing cytopathic effects and lysis in susceptible cell lines at temperatures of 5 to $25^{\circ} \mathrm{C}$. Persistent infection was observed in several fish cell lines. The virus particles were enveloped, and were icosahedral in shape with about $80 \mathrm{~nm}$ in diameter with a central electron-dense core. The virus was replicated with IUdR and BVdU, and inclusion bodies in the infected cells were stained with acridine orange. The virus density was $1.155 \mathrm{~g} / \mathrm{ml}$ and the viral RNA was $7.3 \mathrm{~kb}$ in length. The virus was stable to $\mathrm{pH}$, diethyl ether and chloroform. The virus was not neutralized by antisera against known 6 fish viruses.
\end{abstract}

Key words : new virus, abnormal swimming, coho salmon, masu salmon, rainbow trout, iwana, ayu

In May 1991, a previously undescribed disease was observed in rainbow trout (Oncorhynchus mykiss) cultured in Aomori Prefecture, Japan. The affected fish showed an abnormal spinning motion in juveniles and lethargic behavior in adults, but no extensive losses were observed. From May to July of the following year, the same disease was observed among fries of masu salmon (O. masou) and juveniles of rainbow trout, coho salmon ( $O$. kisutch), iwana (Salvelinus pluvius), and ayu (Plecoglossus altivelis) in Miyagi and Iwate Prefectures, and Hokkaido.

Examination of diseased fish failed to show any bacterial, fungal or parasitic agents infecting these hosts. During the course of viral examination, a cytopathic effects (CPE) similar to that of infectious hematopoietic necrosis virus (IHNV) was observed in the chinook salmon embryo cell line (CHSE-214, Lannan et al., 1984).

In this report, we describe the biochemical, biophysical, and serological characteristics of the isolated virus.

\section{Materials and Methods}

\section{Fish examination}

The viral study was carried out from May 1991 to September 1992. In addition to normal masu salmon, moribund fishes showing abnormal swimming or lethargic behaviors in fries of cultured masu salmon, and juvenile and adults of rainbow trout, coho salmon, iwana and ayu were collected from northern part of Japan (Table 1). Sampled tissues or ovarian fluids were brought to the laboratory in plastic bags with ice and served for virological examinations.

\section{Viruses tested}

Viruses were isolated from diseased and normal fishes by usual method using CHSE-214 cell line. Five different isolates and one cloned isolate were used for virological and serological studies. Strain BrCo-9221 was isolated from the brain of diseased coho salmon in Miyagi Prefecture, and the BrAy9201 and BrIw-9201 were from moribund ayu and iwana fry, respectively, in Iwate Prefecture in June 1992. The strain BrRt-9203 obtained from the brain 
of diseased rainbow trout and strain OvMs-9202 was isolated from ovarian fluid of apparently normal mature masu salmon in Miyagi Prefecture in October 1992, respectively. Cloning of strain BrCo-9221 was performed by methylcellulose-overlayed plaque method (Kamei et al., 1987), using CHSE-214 cell line, with viral culture treated by diethyl ether. Infectious pancreatic necrosis virus (IPNV, strain VR-299), infectious hematopoietic necrosis virus (IHNV, strain HV-1), Oncorhynchus masou virus (OMV, strain OO-7812), chum salmon virus (CSV, strain ToKS-7801) and hirame rhabdovirus (HRV, strain $8401-\mathrm{H}$ ) were used as reference viruses for comparison with the new isolates.

\section{Virus infectivity}

Virus infectivity was measured by $\operatorname{TCID}_{50}$ assay using CHSE-214 cells incubated at $15^{\circ} \mathrm{C}$ for 7 days. The infectivity was determined using 96 well microplates (Falcon) and the end points were calculated by the method of Reed and Muench (1938).

\section{Cell lines}

CHSE-214 cells were used for primary isolation and for routine propagation of the virus. The other 31 cell lines were used to test the virus susceptibility (Table 2). The cells were grown in Eagle's minimum essential medium prepared with Earle's salt (MEM; Gibco), supplemented with $10 \%$ fetal bovine serum (FBS; Flow) and antibiotics (100 I.U. penicillin $/ \mathrm{ml}$; $100 \mu \mathrm{g}$ streptomycin/ml, Sigma). Except where noted, virus inoculated cells were incubated at $15^{\circ} \mathrm{C}$.

\section{Cell line susceptibility}

Monolayer cultures of 32 cell lines were prepared in 96 well plates. Stock culture of $\mathrm{BrCo}-9221$ was diluted $10^{1}$ to $10^{9}$ times in HBSS, $50 \mu l$ of each dilution was inoculated into four wells of each cell line and the virus infectivity was determined.

\section{Persistent infection of cells}

For the study of persistent infection, the 32 cell lines were prepared in $25 \mathrm{~cm}^{2}$ flasks and the strain BrCo-9221 was inoculated at multiplicity of infection $($ M.O.I. $)=1$. The inoculated cells were incubated at $15^{\circ} \mathrm{C}$. On the day of 30 th after inoculation, the cell regeneration after formation of CPE was checked. All of the regenerated cells were scraped out and washed 3 times with HBSS (centrifugation at $200 \mathrm{~g}$ for $15 \mathrm{~min}$ ). The collected cells were counted with hemocytometer (Erma), and seeded in 12 well plate (Corning) at the concentration of $2.5 \times 10^{5} \mathrm{cells} / \mathrm{ml}$. After 1 week culture, the virus infectivity of the culture fluid was determined. For the detection of the virus in the regenerated cells, fluoresent antibody test (FAT) was used with an antirabbit serum against the strain BrCo-9221. Virus infectivity of the culture fluid and cultured cell of persistently infected CHSE-214 cell line, one of the cell lines in which persistent infection were established with BrCo-9221, was determined weekly.

\section{Optimum temperature for virus replication in CHSE- 214 cells}

Monolayer cultures of CHSE-214 cell line were prepared in $25 \mathrm{~cm}^{2}$ flasks and inoculated with the BrCo-9221 at M.O.I. =1. After two hours adsorption, cells were washed with HBSS and MEM-10 was then added. The cultures were incubated at $5,10,15$, 20, 25 and $30^{\circ} \mathrm{C}$. At 1, 3, 5, 7, 9 and 10 days post-inoculation, the virus infectivity in each flask was determined.

Effect of 5-iododeoxyuridine (IUdR) and bromovinyl deoxyuridine $(B V d U)$ on replication of the virus

Monolayer cultures of CHSE-214 cells were first exposed to $10^{-4} \mathrm{M} I U d R$ and BVdU (test cultures), or to HBSS (control). The cultures were infected with the 5 isolates, incubated at $15^{\circ} \mathrm{C}$ for 10 days, and the virus infectivity was measured.

\section{Acridine orange stain}

Monolayer cultures of CHSE-214 cells were grown on $1.5 \mathrm{~cm}^{2}$ cover slips and inoculated with the 5 isolates at M.O.I. $=0.1$. Controls and infected cells were incubated for $48 \mathrm{~h}$ at $15^{\circ} \mathrm{C}$. They were fixed and stained with acridine orange by the method of Rovozzo and Burke (1973), and examined by fluorescent microscopy.

\section{Heat lability}

The virus suspension was distributed in $0.5 \mathrm{~m} l$ aliquots into kahn tubes which were placed in water baths maintained at $50^{\circ} \mathrm{C}$ and $60^{\circ} \mathrm{C}$. At specified times thereafter samples were removed and rapidly cooled, and the remaining virus infectivity was measured.

\section{Ether sensitivity}

One $\mathrm{ml}$ of diethyl ether was mixed to $4 \mathrm{ml}$ of 
culture fluid from an infected cell culture. This mixture and a control tube containing HBSS in place of the ether were allowed to stand at $4^{\circ} \mathrm{C}$ for $18 \mathrm{~h}$. The ether was then removed using nitrogen gas and the virus infectivity in the aqueous phase and the control sample were titrated.

\section{Chloroform sensitivity}

One $\mathrm{ml}$ of chloroform was mixed with $2 \mathrm{ml}$ of virus suspension at room temperature. The mixtures were shaken for $10 \mathrm{~min}$ and centrifuged at $600 \times g$ for $5 \mathrm{~min}$ to separate the chloroform from the aqueous phase of the treated sample. The virus infectivity in treated and control (without chloroform) samples were measured.

\section{Stability to $\mathrm{pH}$ levels}

Stability to selected $\mathrm{pH}$ levels, from $\mathrm{pH} 1$ to 9 was tested by incubating a suspension of virus in MEM adjusted to each $\mathrm{pH}$ by addition of $0.1 \mathrm{~N} \mathrm{HCl}$ or $\mathrm{NaOH}$. After $3 \mathrm{~h}$ incubation at $15^{\circ} \mathrm{C}$, the virus infectivity was titrated.

\section{Hemagglutination with the erythrocytes}

Hemagglutinating activity of the virus on human O-type, rabbit, coho and masu salmon erythrocytes was determined using the microtiter method fo Winton et al. (1981). The erythrocytes were pelleted by centrifugation at $200 \times g$ for $10 \mathrm{~min}$, washed five times with $0.85 \% \mathrm{NaCl}$, and resuspended at a concentration of $0.5 \%$ in phosphate buffered saline (PBS). Serial two-fold dilutions of virus suspension was prepared in PBS, and $50 \mu l$ of cell suspension was added to each well and the microplates were incubated at room temperature overnight.

\section{Virus purification}

Concentration of the virus was achieved by ultracentrifugation. After low speed centrifugation at $4,000 \times g$ for $20 \mathrm{~min}$, the supernatant was collected and pelleted at $80,000 \times g$ for $2 \mathrm{~h}$. The pellet was again ultracentrifuged at $100,000 \times g$ for $2 \mathrm{~h}$ through nonlinear sucrose gradients, 10 and $50 \%(\mathrm{~W} / \mathrm{V})$ sucrose. The virus band formed was removed and applied on linear sucrose gradient of 10 to $50 \%$ $(\mathrm{W} / \mathrm{V})$, and centrifuged at $100,000 \times g$, for $2 \mathrm{~h}$. To determine the virus density, centrifugation was continued for $12 \mathrm{~h}$. After centrifugation, the gradient was fractionated into $200 \mu l$ samples. The refractive index of each fraction was determined with a refrac- tometer (Atago), the buoyant density was then calculated, and the virus infectivity of each fraction was determined by microplate method. The virus was then resuspended in TE buffer $(20 \mathrm{mM}$ tris- $\mathrm{HCl}, 1$ mM EDTA, $\mathrm{pH}$ 7.2) and finally precipitated at $100,000 \times g$ for $2 \mathrm{~h}$. The pelleted virus was then resuspended in TE buffer and dialyzed overnight against TE buffer.

\section{Viral RNA isolation}

Total RNA was extracted using RNAzol B (Cinna/Biotex) according to the manufacturer's instructions. A $100 \mu l$ of purified virus was digested for $10 \mathrm{~min}$ at $4{ }^{\circ} \mathrm{C}$ by addition of $900 \mu \mathrm{l}$ RNAzol B. The solution was triturated, placed in a $1.5 \mathrm{ml}$ microcentrifuge tube with chloroform, and chilled on ice for $10 \mathrm{~min}$. The aqueous phase was separated by centrifugation at $12,000 \times g$ for $15 \mathrm{~min}$ at $4^{\circ} \mathrm{C}$, and the RNA was precipitated with isopropyl alcohol. After centrifugation, the pelleted RNA was washed with $80 \%$ ethanol and dried in a freeze dryer (Labconco). The final pellet was resuspended in $50 \mu l$ buffer. One of non-treated RNA sample (about 5 $\mu \mathrm{g}$ ) and 2 of treated samples (RNase A, $10 \mathrm{mg} / \mathrm{ml}$ and DNase I $5 \mathrm{mg} / \mathrm{ml}$ ) were electrophoresed with $1 \%$ formaldehyde-denaturing agarose method by Martineau et al. (1991).

\section{Antiserum preparation}

A New Zealand white rabbit was injected intramuscularly with an emulsion of purified virus and Freund's incomplete adjuvant $(1: 1)$, and boosted with purified virus intravenously. The intravenous injections were carried out on day 30,50 and 60 after the primary inoculation. The rabbit was bled 10 days after the last injection. Serum was collected, sterilized by membrane filtration, inactivated at $56^{\circ} \mathrm{C}$ for 30 min and stored at $-80^{\circ} \mathrm{C}$ until use.

Antiserum against IHNV (HV-1) was provided by the Japan Fisheries Resource Conservation Association and antiserum against VHSV was provided by Dr. P. de Kinkelin (Institute national de 1a Recherche Agronomique, France), and anti IPNV (VR 299), HRV, OMV and CSV sera were prepared in our laboratory.

\section{Serological characterization tests}

The serological relationships between isolates and the reference viruses were determined by crossneutralization tests using rabbit antisera. Antisera 
were diluted with HBSS at $\mathrm{pH} 7.2$ in either 2 or 10 fold steps. Each virus was harvested and diluted with HBSS to give approximately $100 \mathrm{TCID}_{50}$ per 50 $\mu l$. Fifty microliter aliquots of the virus suspension were reacted with $50 \mu l$ of each antiserum dilution at $15^{\circ} \mathrm{C}$ for $1 \mathrm{~h}$. Then, $100 \mu \mathrm{l}$ volume of CHSE-214 cells $\left(2.0 \times 10^{4}\right.$ cells/well $)$ were added to each reaction mixture. The resulting cultures were incubated at $15^{\circ} \mathrm{C}$ for 10 days and observed for CPE. Neutralizing antibody titers $\left(\mathrm{ND}_{50}\right)$ were expressed as the reciprocal of the highest dilution of antiserum protecting $50 \%$ of the infection of inoculated cell cultures.

\section{Electron microscopy}

The CHSE-214 cells infected with isolated and the cloned strain BrCo-9221 were fixed with $2 \%$ glutaraldehyde in $0.1 \mathrm{M}$ sdium cacodylate buffer ( $\mathrm{pH} 7.4$ ) for $1 \mathrm{~h}$ and then post fixed with $1 \% \mathrm{OsO}_{4}$ in $0.2 \mathrm{M}$ sodium cacodylate buffer for $30 \mathrm{~min}$. The infected cells were embedded in eopxy resin, sectioned and stained with $2 \%$ uranylacetate and lead citrate. Purified virus particles were negatively stained with $2 \%$ uranylacetate on collodion coated grids. All sample grids were examined in a Hitachi H-700 transmission electron microscopy.

\section{Results}

Virus isolation

Virus isolation from moribund fishes showing ab- normal swimming and lethargic behavior at 6 different places in the northern part of Japan and normal matured masu salmon is shown in Table 1. Many moribund fishes showed viral infection in the brain and kidney. The virus was also isolated from about $10 \%$ of normal matured masu salmon population of spawning size.

\section{Cytopathic effect of isolates}

Marked cytopathic effects (CPE) was observed in the CHSE-214 monolayers after 3 to 4 days incubation at $15^{\circ} \mathrm{C}$ (Fig. 1a). The entire cell sheet was almost lysed until 14 days (Fig. 1b). However, a few cells survived and started to replicate from about 21 days after inoculation (Fig. 1c). About one month after inoculation, the regenerated cells formed a cell monolayer again (Fig. 1d).

\section{Susceptibility of cell lines and persistent infection}

The susceptibilities of 32 fish cell lines to $\mathrm{BrCo}-$ 9221 are summerized in Table 2 . In the fish cell lines of BF-2, CHSE-214, CHH-1, RTE-2, SF-2, EO-2, KO-6, RTH-149, ITOF, RTG-2, SE, SEH, SHH, EPG, FHM, RTT and EK-1, the isolated virus developed the CPE and showed the high infectivity. In CCO, EPC, YNK, ASE, AF-29 and JSKG cells, moderate virus infectivity was observed. While, in KRE, KRE-2 and PAS, the virus showed low infectivity. The isolate did not show the CPE in FRF, GSE, MSE, RF, SBK, and WSF cells. Persistent infection of the virus was observed in CHSE-214,

Table 1. Sampled fish and rate of virus isolation

\begin{tabular}{|c|c|c|c|c|c|}
\hline \multicolumn{2}{|c|}{ Origin } & \multicolumn{3}{|c|}{ Fish } & \multirow{2}{*}{ Isolation*1 } \\
\hline Year & Place & Species & Weight*2 & Organ & \\
\hline 1991 & Aomori & $\begin{array}{l}\text { Rainbow trout } \\
\text { (Oncorhynchus mykiss) }\end{array}$ & 450 & $\begin{array}{l}\text { Brain } \\
\text { Kidney }\end{array}$ & $\begin{array}{ll}5 / & 5 \\
5 / & 5\end{array}$ \\
\hline 1992 & Hokkaido & $\begin{array}{l}\text { Masu salmon } \\
\text { (O. masou) }\end{array}$ & 4 & Kidney & $12 / 12$ \\
\hline 1992 & Miyagi & $\begin{array}{l}\text { Rainbow trout } \\
\text { (O. mykiss) }\end{array}$ & 38 & $\begin{array}{l}\text { Brain } \\
\text { Kidney }\end{array}$ & $\begin{array}{ll}4 / & 4 \\
3 / & 4\end{array}$ \\
\hline 1992 & Miyagi & $\begin{array}{l}\text { Coho salmon } \\
\text { (O. kisutch) }\end{array}$ & 27 & $\begin{array}{l}\text { Brain } \\
\text { Kidney }\end{array}$ & $\begin{array}{l}39 / 41 \\
27 / 29\end{array}$ \\
\hline 1992 & Iwate & $\begin{array}{l}\text { Iwana } \\
\text { (Salvelinus pluvius) }\end{array}$ & 14 & $\begin{array}{l}\text { Brain } \\
\text { Kidney }\end{array}$ & $\begin{array}{ll}2 / & 4 \\
1 / & 4\end{array}$ \\
\hline 1992 & Iwate & $\begin{array}{l}\text { Ayu } \\
\text { (Plecoglossus altivelis) }\end{array}$ & 19 & $\begin{array}{l}\text { Brain } \\
\text { Kidney }\end{array}$ & $\begin{array}{ll}3 / & 5 \\
3 / & 5\end{array}$ \\
\hline 1992 & Miyagi & $\begin{array}{l}\text { Masu salmon*3 } \\
(\text { O. masou })\end{array}$ & 1500 & $\mathrm{OvF}^{* 4}$ & $13 / 120$ \\
\hline
\end{tabular}

${ }^{* 1}$ No. of positive/No. of tested fish, ${ }^{* 2}$ Average weight in gram, ${ }^{* 3}$ Normal fish, ${ }^{* 4}$ Ovarian fluid. 

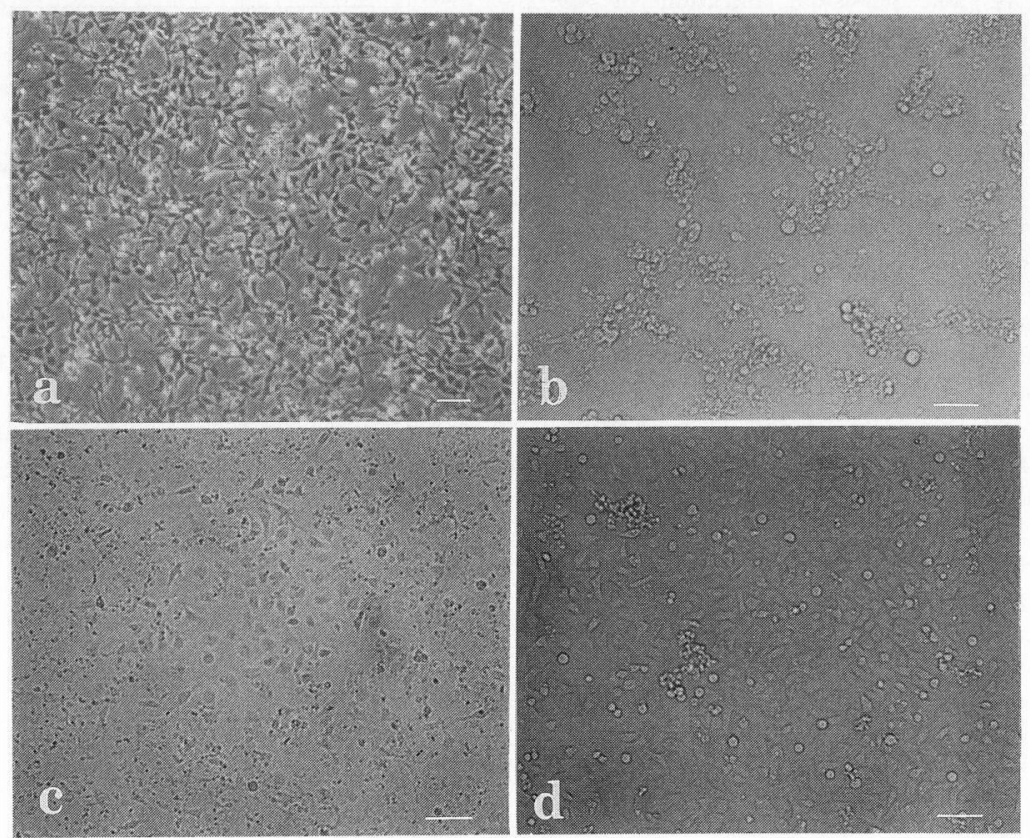

Fig. 1. Cytopathic effects produced in a chinook salmon embryo cell line (CHSE-214) by the isolated virus strain BrCo-9221.

a: 3 days post inoculation (p.i.), the cells undergo entire and lysis, b: 2 weeks p.i., lysis of entire cell seat, c: 3 weeks p.i., some survived cells regenerated, d: 4 weeks p.i., the cells were completely recovered. Scale bar $=30 \mu \mathrm{m}$.

CHH-1, EO-2, KO-6, SHH, EK-1, CCO, EPC, and AF-29. In the regenerated CHSE-214 cells, high level of infective virions were produced and the virus infectivity was persistently maintained in subcultures of the cells (Fig. 2).

\section{Growth temperature}

The virus grew well between 10 to $25^{\circ} \mathrm{C}$ with the optimum growth temperature at $15^{\circ} \mathrm{C}$ (Fig. 3). The maximum virus infectivity was obtained with $10^{9.25}$ $\mathrm{TCID}_{50} / \mathrm{ml} 5$ days after inoculation. No evidence of virus replication was found at $30^{\circ} \mathrm{C}$.

\section{Buoyant density and electron microscopy}

Virions could be partially purified from infected cells using sucrose gradients. The peak of virus infectivity was observed in a band formed in sucrose gradient, and no infectivity was detected in other fraction. The buoyant density corresponding the peak was calculated approximately $1.155 \mathrm{~g} / \mathrm{ml}$ in sucrose.

Electron microscopy showed that the band formed in sucrose gradient contained numerous enveloped icosahedral shape virions with a diameter about 80 $\mathrm{nm}$ (Fig. 4). Two type of virus particles were observed; unenveloped virions about $65 \mathrm{~nm}$ in diameter with a electron-dence core virus particles (Fig. 5a) and about $80 \mathrm{~nm}$ enveloped virions (Fig. 5b), which were observed in cytoplasm of infected CHSE-214 cells. Clone purified virus showed the same shape of the enveloped virions, and both kinds of virions were observed in the infected CHSE-214 cell.

\section{Biochemical and biophysical characteristics}

Biochemical and biophysical characteristics of the isolates are summarized in Table 3. The deoxyuridine analogues IUdR and BVdU were not effective in blocking viral replication. The replication of the reference RNA virus, IPNV, was also not affected by the presence of IUdR and BVdU in the medium. In contrast, DNA virus OMV was completely inhibited by the presence of IUdR and BVdU. In infected cells stained with acridine orange, the cytoplasm con- 
Table 2. Infectivity and persistent infection of the isolated virus strain $\mathrm{BrCo}-9221$ in selected fish cell lines

\begin{tabular}{|c|c|c|c|}
\hline Cell line & Species & $\begin{array}{l}\text { maximum } \\
\text { virus } \\
\text { infectivity }\end{array}$ & $\begin{array}{l}\text { Presistent } \\
\text { infection*1 }\end{array}$ \\
\hline BF-2 & Bluegill & $8.55^{* 2}$ & $\mathrm{ND}^{* 3}$ \\
\hline CHSE-214 & Chinook salmon & 8.55 & 6.80 \\
\hline CHH-1 & Chum salmon & 8.05 & 7.05 \\
\hline RTE-2 & Rainbow trout & 7.55 & ND \\
\hline SF-2 & Smelt & 7.55 & ND \\
\hline EO-2 & Eel & 7.30 & 6.05 \\
\hline KO-6 & Kokanee salmon & 7.30 & 5.80 \\
\hline RTH-149 & Rainbow trout & 7.30 & ND \\
\hline ITOF & Ito & 7.05 & ND \\
\hline RTG-2 & Raibow trout & 7.05 & ND \\
\hline $\mathrm{SE}$ & Chum salmon & 7.05 & ND \\
\hline SEH & Chum salmon & 7.05 & ND \\
\hline SHH & Snakehead & 7.05 & 6.30 \\
\hline EPG & Goldfish & 6.55 & ND \\
\hline FHM & Minnow & 6.55 & ND \\
\hline RTT & Rainbow trout & 6.55 & ND \\
\hline EK-1 & Eel & 6.30 & 5.05 \\
\hline $\mathrm{CCO}$ & Channel catfish & 5.80 & 5.30 \\
\hline EPC & Carp & 5.55 & 4.05 \\
\hline YNK & Yamame & 5.55 & ND \\
\hline ASE & Atlantic salmon & 5.30 & ND \\
\hline AF-29 & Ayu & 4.55 & 4.05 \\
\hline JSKG & $\begin{array}{l}\text { Japanese striped } \\
\text { knife jaw }\end{array}$ & 4.55 & ND \\
\hline KRE & $\begin{array}{l}\text { Kelp \& red spotted } \\
\text { grouper }\end{array}$ & 2.80 & ND \\
\hline KRE-2 & Hybrid of grouper & 2.80 & ND \\
\hline PAS & Purplish amberjack & 2.80 & ND \\
\hline FRF & Kitunemebaru & -*4 & $\mathrm{NT}^{* 5}$ \\
\hline GSE & Gizzardshad & - & NT \\
\hline MSE & Masu salmon & - & NT \\
\hline RF & Kurosoi & - & NT \\
\hline SBK & Red Seabream & 一 & NT \\
\hline WSF & White sardine & - & NT \\
\hline
\end{tabular}

*1 Persistent infection was shown by virus infectivity $\left(\log _{10} \mathrm{TCID}_{50} / \mathrm{ml}\right)$ of culture fluid, ${ }^{* 2} \log _{10} \mathrm{TCID}_{50} / \mathrm{ml}$, ${ }^{* 3}$ Not detected, ${ }^{* 4}$ CPE was not developed, ${ }^{* 5}$ Not tested.

tained orange colored inclusion bodies. Formaldehyde agarose gel electrophoretic analysis of RNA prepared from purified virions showed $7.3 \mathrm{~kb}$ in length. The $7.3 \mathrm{~kb}$ RNA was sensitive to RNase A treatment, but the RNA band did not change when treated with DNase I.

Ether and chloroform treatment did not reduce

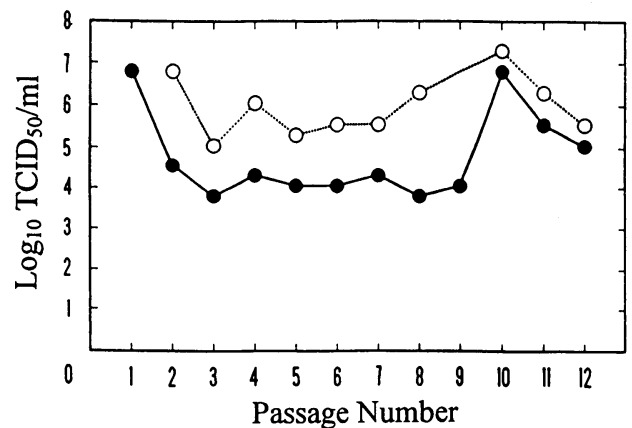

Fig. 2. Virus infectivity in CHSE-214 cell line persistently infected with the isolated virus strain BrCo-9221. Persistently infected cells were subcultured at one week interval. The infectivity of cell free $(O)$ and cell associated $(O)$ virus were determined weekly.

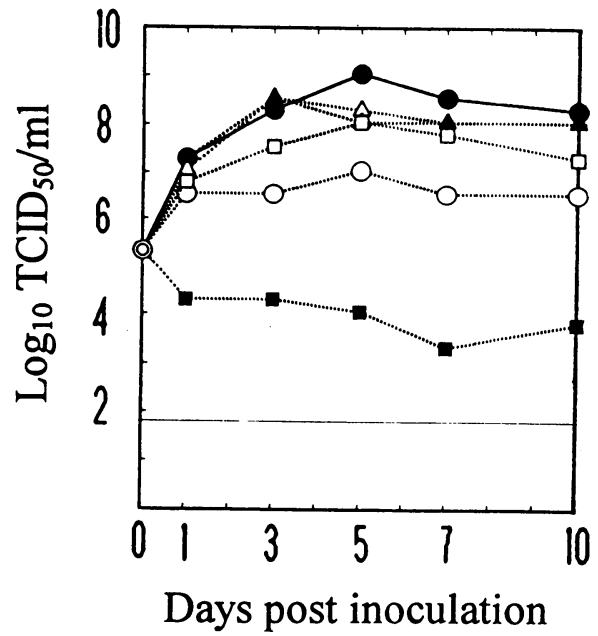

Fig. 3. Replication of isolated virus strain BrCo-9221 in CHSE-214 cell line incubated at six different temperatures.

$\bigcirc, 5^{\circ} \mathrm{C} ; \triangle, 10^{\circ} \mathrm{C} ; \bigcirc, 15^{\circ} \mathrm{C} ; \Delta, 20^{\circ} \mathrm{C}$ $25^{\circ} \mathrm{C} ; \square, 30^{\circ} \mathrm{C}$

infectivity of the isolates, and the same results was obtained in cloned virus. In contrast, infectivity of IHNV was completely lost when treated similarly.

The isolated viruses were partially inactivated by exposure to $\mathrm{pH} 1$ but treatment at $\mathrm{pH} 2$ to 9 showed no effects on viral infectivity. These isolates were stable at high temperatures, i.e. keeping at $60^{\circ} \mathrm{C}$ for $30 \mathrm{~min}$. No hemagglutination with human $\mathrm{O}$ type, rabbit, or fish (coho and masu salmon) erythrocytes was observed. 


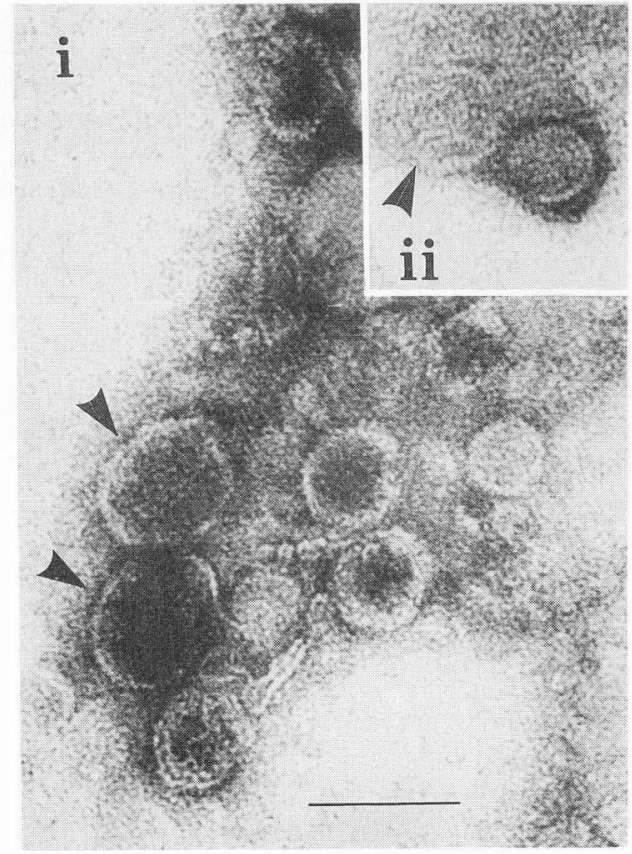

Fig. 4. Negatively stained isolated virus strain BrCo9221. Enveloped virus particles (arrow head, i and ii). Scale bar $=100 \mathrm{~nm}$.

\section{Serological characteristics}

By the cross-neutralization tests, the isolated virus strain BrCo-9221 was clearly distinguishable from the five reference fish viruses (Table 4 ). The five isolates were neutralized with antiserum against strain BrCo-9221 at a titer of $1: 960$ to $1: 2560$. However, cross reaction to anti-IHNV, IPNV, VHSV, OMV and CSV rabbit sera was not observed.

\section{Discussion}

The virus described here was isolated from salmonids and ayu which are cultured in the northern part of Japan and showed an abnormal swimming and lethargic behavior. Primary CPE of the virus manifested as generalized cell lysis, but, the survived cells regenerated and multiplied after obiously lysed. The regeneratd cells produced a large number of virions and virus replication was persistently maintained. Negatively stained virions showed an icosahedral shape with a mean diameter of $80 \mathrm{~nm}$, with envelope. However, in the infected cell cytoplasm, both non enveloped small virus particles $(65 \mathrm{~nm}$ in diameter) and enveloped virus particles $(80 \mathrm{~nm}$ in diameter) were observed. The viral replication was not affected by the presence of IUdR and BVdU in

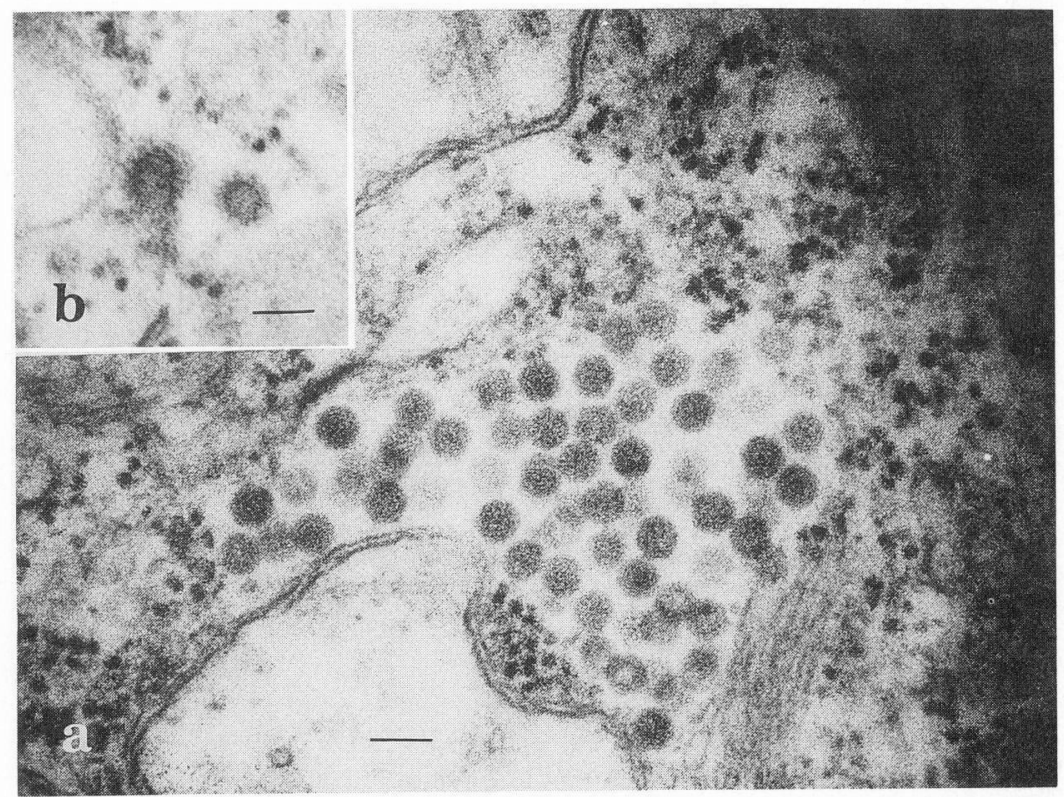

Fig. 5. Unenveloped icosahedral virus particles (a) and enveloped virus particles (b) in cytoplasm of CHSE214 cell. Scale bar $=100 \mathrm{~nm}$. 
Table 3. Biochemical and biophysical characteristics of the isolated virus strains

\begin{tabular}{|c|c|c|c|c|c|c|c|c|}
\hline \multirow{2}{*}{ Characterization } & \multicolumn{5}{|c|}{ Strains (titer: $\log _{10} \mathrm{TCID}_{50} / \mathrm{m} l$ ) } & \multicolumn{3}{|c|}{ References virus } \\
\hline & BrRt-9203 & BrCo-9221 & BrIw-9201 & BrAy-9201 & OvMs-9202 & IPNV & INHV & OMV \\
\hline \multicolumn{9}{|l|}{ Susceptibility } \\
\hline to IUdR & 7.30 & 7.80 & 8.05 & 7.80 & 7.80 & 7.55 & NT & $<1.80$ \\
\hline BVdU & 7.55 & 7.55 & 8.05 & 7.55 & 7.55 & 7.30 & NT & $<1.80$ \\
\hline Control & 7.55 & 7.55 & 8.30 & 7.80 & 8.05 & 7.55 & $\mathrm{NT}^{* 1}$ & 5.05 \\
\hline \multicolumn{9}{|l|}{ Sensitivity } \\
\hline to Ether & 6.80 & 8.30 & 7.80 & 8.05 & 8.30 & 8.55 & $<1.80$ & NT \\
\hline Chloroform & 6.55 & 8.30 & 7.80 & 7.80 & 8.30 & 8.30 & $<1.80$ & NT \\
\hline Control & 6.80 & 8.30 & 7.80 & 8.05 & 8.55 & 8.30 & 6.05 & NT \\
\hline \multicolumn{9}{|l|}{ Stability } \\
\hline to $\mathrm{pH} 1$ & 6.55 & 4.05 & 5.05 & 4.30 & 3.80 & 7.05 & NT & NT \\
\hline pH 2 & 7.80 & 8.05 & 8.05 & 6.80 & 8.30 & 8.05 & NT & NT \\
\hline $\mathrm{pH} 3$ & 7.80 & 8.30 & 8.55 & 7.80 & 8.05 & 8.30 & $<1.80$ & NT \\
\hline pH 5 & 8.05 & 8.05 & 8.30 & 7.55 & 8.55 & 8.30 & 3.55 & NT \\
\hline $\mathrm{pH} 7$ & 8.05 & 8.30 & 8.55 & 7.55 & 8.55 & 8.30 & 5.05 & NT \\
\hline pH 9 & 8.30 & 8.30 & 8.55 & 7.30 & 8.30 & 8.30 & 5.05 & NT \\
\hline \multicolumn{9}{|l|}{ Heat lability } \\
\hline$\left(50^{\circ} \mathrm{C}, 15 \mathrm{~min}\right)$ & NT & 8.05 & NT & NT & NT & 7.30 & NT & $<1.80$ \\
\hline$\left(60^{\circ} \mathrm{C}, 30 \mathrm{~min}\right)$ & NT & 7.80 & NT & NT & NT & 7.55 & NT & $<1.80$ \\
\hline Untreated & NT & 8.30 & NT & NT & NT & 7.30 & NT & 5.30 \\
\hline \multicolumn{9}{|l|}{ Hemagglutination } \\
\hline Human 0 type & NT & —2 & NT & NT & - & NT & NT & NT \\
\hline Rabbit & NT & - & NT & NT & - & NT & NT & NT \\
\hline Coho salmon & NT & - & NT & NT & - & NT & NT & NT \\
\hline Masu salmon & NT & - & NT & NT & - & NT & NT & NT \\
\hline
\end{tabular}

${ }^{* 1}$ Not tested, ${ }^{* 2}$ negative.

Table 4. Cross-neutralization tests with anti-sera against IHNV, IPNV, VHSV, OMV, CSV and isolated virus strain BrCo-9221

\begin{tabular}{|c|c|c|c|c|c|c|c|}
\hline \multirow{2}{*}{ Virus } & \multirow{2}{*}{$\begin{array}{c}\text { Titer } \\
\log _{10} \text { TCID }_{50} / \text { well }\end{array}$} & \multicolumn{6}{|c|}{ Anti-sera $\left(N D_{50}\right)^{* 1}$} \\
\hline & & BrCo-9221 & IHNV & IPNV & VHSV & OMV & CSV \\
\hline \multicolumn{8}{|l|}{ Isolated strain } \\
\hline BrRt-9203 & 1.80 & 960 & $<20$ & $<20$ & $<40$ & $<20$ & $<20$ \\
\hline BrCo-9221 & 2.05 & 2560 & $<20$ & $<20$ & $<40$ & $<20$ & $<20$ \\
\hline BrIw-9201 & 2.05 & 2560 & $<20$ & $<20$ & $<40$ & $<20$ & $<20$ \\
\hline BrAy-9201 & 2.30 & 1280 & $<20$ & $<20$ & $<40$ & $<20$ & $<20$ \\
\hline OvMs-9202 & 2.05 & 1600 & $<20$ & $<20$ & $<40$ & $<20$ & $<\mathbf{2 0}$ \\
\hline IHNV & 1.80 & $<40$ & 160 & $\mathrm{NT}^{* 2}$ & NT & NT & NT \\
\hline IPNV & 1.55 & $<40$ & NT & 1120 & NT & NT & NT \\
\hline OMV & 1.80 & $<20$ & NT & NT & NT & 105 & NT \\
\hline CSV & 2.05 & $<12$ & NT & NT & NT & NT & 24 \\
\hline
\end{tabular}

${ }^{* 1} 50 \%$ neutralization titer, ${ }^{* 2}$ Not tested. 
the medium. The lack of inhibition by halogenated pyrimidines and the sensitivity to RNase suggests that the virus possesses an RNA genome. In addition, orange colored inclusion bodies were observed in the infected cell cytoplasms by acridine orange stain, suggesting the existence of single stranded nucleic acids. Virus RNA was shown $7.3 \mathrm{~kb}$ in length, and the virion density was $1.155 \mathrm{~g} / \mathrm{ml}$ in sucrose gradients. On reverse transcriptase (RT) assays with $(\mathrm{rCm}) \mathrm{n}(\mathrm{dG})_{12-18}$ as the primer for $\mathrm{RT}$ activity of mouse retrovirus, this isolated virus had RT activity (data was not shown). We can not find any known fish virus that have characteristics similar to those of present virus. Thus, this virus isolated from salmonid fish that showed abnormal swimming and letargic behavior seems to be a new fish virus.

Characteristics of the isolate are similar to the Retroviridae. Generally, retrovirus have 8 structural protein (MA, CA, NC, PR, RT, IN, SU, TM) and 7 to $10 \mathrm{~kb}$ RNA. The virion density is between 1.16 and $1.18 \mathrm{~g} / \mathrm{ml}$ in sucrose, and they have RT activity (White and Fenner, 1986; Doane and Andersen, 1987; Coffin, 1990). Recently some retroviruses have been reported to induce proliferative consitions in salmonid fish (Duncan, 1978; McKnight, 1978; Kent et al., 1990). Eaton and Kent (1992) reported a retrovirus infection in chinook salmon with plasmacytoid leukemia (PL). Examination of fractions in sucrose gradient from PL-positive fish showed enveloped virus particles of about $110 \mathrm{~nm}$ diameter, with an electron dence core. It had reverse transcriptase (RT) activity and 7 polypeptides observed by polyacrylamide gel electrophoresis. Petry et al. (1992), reported the isolation and characterization of a retrovirus from a non-salmonid fish, genus $X i$ phophorus. The virus particle has a buoyant density of $1.16 \mathrm{~g} / \mathrm{ml}$, a mean diameter of $100 \mathrm{~nm}$, six associated proteins, and RT activity. However, all these fish retroviruses could not be grown in fish cell cultures.

At this time, it is difficult to determine the taxonomical position of this virus with presented results. Generally, the enveloped virus is sensitive to lipid solvent and the sensitivity test to solvent is used to define the virus envelope. The isolated new virus has envelope by the EM observation, but resistant to diethyl ether and chloroform. The cloned virus also showed the same characteristic to the ether treatment. In order to determine the taxonomical position of this virus, the supplemental studies of envelope composition, protein structure, property of RT and genetic construction of RNA are needed. The works are currently under way.

\section{Acknowledgements}

We would like to express our sincere thanks to Dr. J. L. Fryer, Oregon State University, for his critical review of the paper and valuable suggestions; and Mr. S. Ono, Miyagi Fedration of Fisheries Cooperative Associations, Dr. K. Takahashi, Inland Fisheries Experimental Station of Miyagi Prefecture, and Mr. T. Watanabe, Nihon Nosankogyo Co., Ltd., for providing the fish examined.

\section{References}

Coffin, J. M. (1990): Retroviridae and their replication. In second edition (ed, by B. Fields and D. M. Knipe), "Virology". Raven, NY, pp. 1437-1500.

Doane, J. W. and N. Andersen (1987): Electron microscopy in diagnostic virology. Cambridge University Press, Oakleigh, Melbourne, 178 p.

Duncan, I. B. (1978): Evidence for an oncovirus in swim bladder fibro sarcoma of Atlantic salmon, Salmo salar $\mathbf{L}$. J. Fish Dis., 1, 127-131.

Eaton, W. D. and M. L. Ketn (1992): A retrovirus in chinook salmon (Oncorhynchus tschawytscha) with plasmacytoid leukemia and evidence for the etiology of the disease. Cancer Res., 52, 6496-6500.

Kamei, Y., M. Yoshimizu and T. Kimura (1987): Plaque assay of Oncorhynchus masou virus (OMV). Fish Pathol., 22, 147-152.

Kent, M. L., J. M. Groff, G. S. Traxler, J. G. Zinkl and J. W. Bagshaw (1990): Plasmacytoid leukemia in seawater reared chinook salmon, Oncorhynchus tshawytscha. Dis. Aquat. Org., 8, 199-209.

Lannan, C. N., J. R. Winton and J. L. Fryer (1984): Fish cell lines: Establishment and characterization of nine cell lins from salmonids. In Vitro, 20, 671-676.

Martineau, D., R. Renshaw, J. R. Williams, J. W. Casey and P. R. Bowser (1991): A large unintegrated retrovirus DNA species present in a dermal tumor of walleye Stizostedion vitreum. Dis. Aquat. Org., 10, 153-158.

McKnight, I. J. (1978): Sarcoma of the swim bladder of Atlantic salmon (Salmo salar L.). Aquaculture, 13, 5560.

Petry, H., K. Petry, M. Schmidt, G. Hunsman, F. Anders and W. Luke (1992): Isolation and characterization of a retrovirus from the fish Genus Xiphophorus. Virol., 188, 785-792.

Reed, J. L. and H. Muench (1938): A simple method of estimating fifty percent endpoints. Am. J. Hyg., 27, 493497. 
Rovozzo, G. C. and C. N. Burke (1973): A manual of basic virological techniques. Prentice-Hall, Emnglewood Cliffs, $287 \mathrm{p}$.

White, D. O. and F. Fenner (1986): Medical Virology.
Academic Press, Orlando, Florida, 655 p.

Winton, J. R., C. N. Lannan, J. L. Fryer and T. Kimura (1981): Isolation of a new reovirus from chum salmon in Japan. Fish Pathol., 15, 155-162. 